Ijtihad: Jurnal Wacana Hukum Islam dan Kemanusiaan

Vol. 21, No. 2 (2021), pp. 177-196, doi : 10.18326/ijtihad.v21i2.177-196

\title{
Muhammadiyah constitution jihad movement: a case study of the Omnibus Law on job creation
}

\author{
Muhammad Nurul Huda, Suranto \\ Universitas Mubammadiyah Yogyakarta \\ E-mail:m.nurul.psc19@mail.umy.ac.id,suranto_umy@yahoo.cm
}

\section{Hammam}

Institut Agama Islam Negeri Salatiga

E-mail:hammam@iainsaalatiga.ac.id

\section{Herdin Arie Ssaputra}

Universitas Muhammadiyyah Semarang

E-mail: herdinariesaputra@gmaiil.com

DOI: 10.18326/ijtihad.v21i2.177-196

The Omnibus Law on job creation is a government initiative proposal and it has drawn public reactions to polemics of debate. Muhammadiyah as a religious organisation also expressed their objections to the Omnibus Law on job creation. This article is qualitative research that applies NVivio 12 plus to manage the data through crosstab analysis and cluster analysis. This study shows that there are aspects of conflictual relations that give rise to a movement. Muhammadiyah forms a formal or non-formal organization that involves the Law and Human Rights Council (HAM) as well as s a forum of the dean of the law faculty and the head of the law school of Muhammadiyah and Aisyiyah universities. In the concept, of Muhammadiyah emphasizes to synchronise between institutions by prioritizing transparency, making laws severe in their implementation. Muhammdiyah offers three concept points, namely revoking a government regulation in lieu of law (PERPU), delaying its implementation, and revising through public participation. 
Omnibus Law Cipta Kerja merupakan usul inisiatif pemerintah dan kemunculannya menuai reaksi publik hingga polemik perdebatan. Organisasi keagamaan Muhammadiyah turut menyatakan sikap keberatannya terhadap Omnibus Law Cipta Kerja. Artikel ini adalah kajian kualitatif yang menggunakan NVivo 12Plus untuk mengelola data melalui analisis crosstab dan analisis cluster. Kajian ini menunjukkan ada beberapa aspek hubungan konfliktual yang melahirkan sebuah gerakan. Muhammadiyah membentuk organisasi formal atau non-formal yang melibatkan Majelis Hukum dan Hak Asasi Manusia (HAM), forum dekan fakultas hukum dan ketua sekolah tinggi hukum perguruan tinggi Muhammadiyah dan Aisyiyah. Dalam konsepnya, Muhammadiyah menegaskan pentingnya sinkronisasi antara lembaga dengan mengedepankan transparansi, membuat undang-undang harus serius dalam pelaksanaannya. Muhammadiyah menawarkan tiga poin konsep, yaitu mencabut dengan Peraturan Pemerintah Pengganti Undang-undang (PERPU), menunda pelaksanaannya, dilakukan revisi dengan melibatkan partisipasi publik.

Keywords: Omnibus law; public policy; social movement

\section{Introduction}

Public policy aims to benefit the community and provides problem-solving for public problems. Therefore, responsive public policies can have an impact on sustainably improving community welfare. However, public policy is a product that fights for the public interest, which philosophically requires public involvement from the beginning of its preparation to the end of its ratification (Sururi, 2016, pp. 1-14). Therefore, the government's public policy should be oriented to the community's interests and improve social welfare. The products of these public policies are regulations and legislations (Ramdhani \& Ramdhani, 2017, pp. 1-12). Hence, it cannot be denied that policy products are influenced by various interested parties, such as political elites, capital owners, and other interested actors.

According to Herdiana (2018, pp. 13-26), public policy is part of political decisions and involves several parties. Public policies do not reflect the wider community's interests (Manulu, 2016, pp. 27-50). As a result, public policies are potentially vulnerable to conflict because political elites tend to accommodate the interests of capital owners rather than the interests of the people at large. Nevertheless, it can have an impact on the life of the nation and state.

In Indonesia, a public policy in the form of the Omnibus Law on job creation is a government initiative proposal, and its emergence has drawn public reactions to polemic debates. Starting with the second term of President Joko Widodo's inauguration speech 
before the people's consultative assembly of the Republic of Indonesia (MPR RI) session on October 20, 2019, he complained about the complexity of investing in Indonesia due to the many rules in the business licensing process. Those rules hampered the improvement of the investment climate in Indonesia (Firmansyah et al., 2020, pp. 131-140).

To maintain a conducive and competitive business and investment climate, the government requires legal certainty to simplify regulations. The facts show that regulations overlap each other, and the conditions of regulations are byper-regulation. The government considers this regulatory problem to be no longer relevant to face the challenges of the industrial revolution 4.0. Therefore, there is a need to simplify regulations through the Omnibus Law (Mayasari, 2020, pp. 1-15; Setiadi, 2020, pp. 39-52; Michael, 2020, pp. 159176).

Omnibus Law is a method of formulating a law consisting of several primary materials by revoking, changing, and adding several laws at once and making it a single document to synchronise and harmonise regulations (Azhar, 2019, pp. 170-178; Setyawan, 2020, pp. 150-164). The following is 11 coverages of the Omnibus Law on Job Creation, namely:

Table 1.

Omnibus Law Cluster Job Creation

\begin{tabular}{cl}
\hline No & \\
\hline $\mathbf{1}$ & Simplification of Licensing \\
$\mathbf{2}$ & Investment Requirements \\
$\mathbf{3}$ & Employment \\
$\mathbf{4}$ & Ease, Empowerment, and Protection of Micro, Small, and Medium Enterprises \\
& (UMKM) \\
$\mathbf{5}$ & Ease of Business \\
$\mathbf{6}$ & Research and Innovation Support \\
$\mathbf{7}$ & Government Administration \\
$\mathbf{8}$ & Imposition of Sanctions \\
\hline
\end{tabular}




\begin{tabular}{cl}
\hline No & \multicolumn{1}{c}{ Description } \\
\hline 9 & The land acquisition \\
10 & Government Investments and Projects \\
11 & Special Economic Zone \\
\hline
\end{tabular}

Source: wnw.dpr.go.id (2020)

Although the Omnibus Law on job creation has now been ratified and is binding on all Indonesian citizens. In the process, the rule has drawn much controversy from the time of its proposal, discussion, and ratification, to it was signed by the president. According to Kristiyanto (2020, pp. 233-244), the government is not transparent and ignores public participation. Whereas public participation plays a vital role in the context of a democratic country. In addition, Kurniawan and Dewanto (2020, pp. 63-76)the legal consequences arising for the heirs as holders of land rights are not guaranteed legal certainty. So it can be said that the heirs cannot take legal actions against the land title certificates","

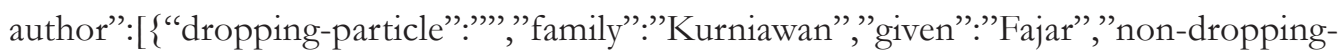

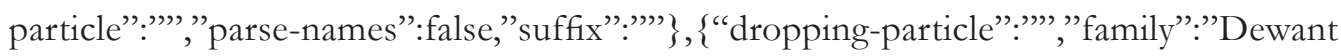

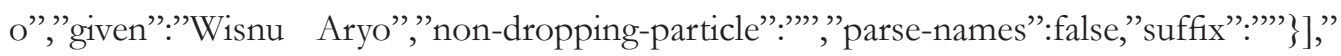

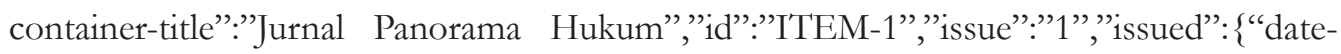
parts":[[“2020"]]\},"page":"63-76","'title":"Problematika Pembentukan Ruu Cipta Kerja Dengan Konsep Omnibus Law Pada Klaster Ketenagakerjaan Pasal 89 Angka 45 Tentang Pemberian Pesangon Kepada Pekerja Yang Di PHK","type":"article-journal","volume":"5 "),"uris":["http://www.mendeley.com/documents/?uuid=8527a03d-3700-445c-a453-b21 d33b5d1a2"]\}],"mendeley": ‘“formattedCitation”:"'(Kurniawan \& Dewanto, 2020 drafting the Omnibus Law on Job Creation was carried out with a short deadline and was influenced by economic factors. This influence had an impact on the procedures and provisions in the process of its formation. For example, they are considered to have narrowed the space for the workers to move and give the entrepreneurs domination to exploit the workers. Hence, it needs to be an intensive dialogue between the government and the community, especially direct impacts on the people (Satria, 2020, pp. 111-118). 
The wave of rejection of the Omnibus Law on job creation was echoed by various labour unions, mass organizations, environmental activists, students, academics, and experts. Several controversial articles get the spotlight from elements of society such as articles on changes to city/district minimum wages, articles on termination of employment (PHK) rules, articles on the ease of absorption of foreign workers, articles on environmental impact analysis (AMDAL) preparation and loss of opportunity to sue, and articles on the authority of regional government under the central government.

Regarding on the lack of public participation, openness to the public, differences in drafts, to the rush in preparation, and the public perception, the Omnibus Law on job creation is a requirement for interests that tend to prioritize the interests of capital owners. This irregularity was considered by many student alliances and labour unions to conduct demonstrations against the Omnibus Law on job creation. The article intends to discuss how the political roles of Muhammadiyah forms the social-jihad movement based on the approach of political opportunity, structure mobilization, and the framing process in the case of the Omnibus Law on job creation policy.

\section{Method}

The research applies a qualitative approach, which the data is conducted by interview, observation, personal documents, memos, and other official documents. This research comprehensively describes the empirical reality behind the phenomenon. Therefore, using a qualitative approach in this research is linked to the empirical reality with the applicable theory by using a descriptive method (Moleong, 2017, pp. 1-37).

The data of this research consists of primary data and secondary data. The primary data were obtained through interviews and observations. Meanwhile, the secondary data was conducted from literature studies of journal articles, published research, laws, and government regulations. The study uses Nvivo 12 Plus software to manage, code, and classify the data (Van Gasse \& Mortelmans, 2020, pp. 1-19). Furthermore, the scope of data analysis through NVivo is very complex, including articles, reports, field notes, and transcripts of interview (Brandão, 2015, pp. 1-3). Particularly, Crosstab Query Analysis and Cluster Analysis of NVivo 12 Plus feature are applied. 
ljtihad: Jurnal Wacana Hukum Islam dan Kemanusiaan, Volume 21, No. 2, Desember 2021: 177-196

\section{Social movement}

The social movement approach has three critical structures, including the political opportunity structure, the mobilizing structure, and the framing process (Ahyar, 2015, pp. 1-26; Fuadi \& Tasmin, 2019, pp. 48-60). Approaches on the phenomenon of social movements include political opportunity structure, resource mobilization theory, and collective action frames (Bendar, 2019, pp. 25-37).

The early women social movement was an effort to elevate the position of women. This movement creates a space that provides equality for women both individually and communally. Ayu Ratih, woman labour activist colours to every liberation movement for eliminating all forms of discrimination and inequality in civilized human relations (Fitri \& Akbar, 2017, pp. 83-102). Public policy changes can occur without waiting for initiatives from state actors (parliament and bureaucracy), but it can also occur because of high pressure of social movements. As various formal mechanisms and channels seem to be closed, social movements can be an effective alternative to changes a public policy (Manulu, 2016, pp. 27-50).

Social movements become a social science discourse that needs to be studied, reviewed, and reinterpreted from various perspectives, including classical and neo-classical thinking, old social movements, and new social movements. Islam is a universal value that talks about halal and haram, and solves social, cultural, and economic problems (Izudin, 2018, pp. 253-274). The revolutionary movement emerged not only because of religious matters, but also participative roles of Muslims and the central issue of the voiced movement was not related to the religion held by the community. However, as long as the revolution took place, Islam could not be separated from the mass organizations (Yasmine, 2016, pp. 106113).

The 212 Movement was religious-based social movements because of the militancy mixed with the voluntary attitude seen in the behaviour of the leaders and the masses of action. Therefore, religion became the primary motive for the new social movement 212 (Badrun, 2019, pp. 254-272)Indonesia using the perspective of the theory of social movements (1848-2013. Muhammadiyah organizationally stated that it was not involved in the movement, but some Muhammadiyah activists involved in mobilizing the Islamic 
defence action movement. Several activists of Muhammadiyah were also involved in the success of the action movement (Amin, 2020, pp. 36-45).

In March 2020, protestors including students opposed the enactment of the Omnibus Law, which was thought to be insufficient to address the community's requirements. As a result, the hashtag omnibus law has become a popular topic on the Twitter. Some points in the omnibus labour copyrights law are deemed detrimental to workers, including the elimination of the minimum wage, the elimination of severance pay, the inclusion of foreign workers, the absence of social security, the elimination of sanctions against employers who violate labour laws, and the expansion of labour market flexibility and outsourcing. The government's ethics in implementing policies exclude the community, creating an omnibus statute in which government ethics is primarily to enforce ethics of behaviour (Perrara, 2016, pp. 1-14; Habibie et al., 2021, pp. 52-58).

The relationship among actors through social media platforms such as Twitter exerts pressure on public opinion in various parts of the world. Forming a network pattern connects countries in response to the issue of Uighur Muslim community intimidation. Social protests by Twitter users constantly use to pressure the Chinese government emerges a new social policy movement led by countries that support the rejection of intimidation (Buntoro et al., 2021, pp. 1-18).

\section{Muhammadiyah's constitutional jihad movement}

It is paying attention to various strategic issues. First, national politics includes the sovereignty and dignity of the nation, criticism of public policies, and other national political conditions from the point of view of national morality. Second is about the relationship among religious communities (Masmuh, 2020, pp. 78-93). The modern Islamic movement can adapt to modern developments and adapt from Islamic teachings into modern thinking and institutions. As Muhammadiyah declared the constitutional jihad movement, it has submitted a judicial review of 4 laws to the Constitutional Court from November 2012 to February 2015. They are the Oil and Gas Law (12 November 2012), the Hospital Law (22 May 2014), Social Organisation Law (23 December 2014), and Water Resources Law (18 February 2015) (Arizona \& Chandranegara, 2017, pp. 25-54; Mubaroq, 2019, pp. 42-49). 
Jihad movement on Muhammadiyah perspective can be based on two things. First, jihad is to build social integration. Second, jihad is to overcome poverty and widen social inequality (Qodir et al., 2015, pp. 1-139). Muhammadiyah carries out political movements, but not practical politics. As an interest group, Muhammadiyah plays political lobbying, political communication, political socialisation, political education, conducting public criticism or pressure, and distributing political cadres or other professional cadres who can enter to government (Nilwani, 2016, pp. 33-43).

Muhammadiyah plays a significant role as a civil society force, although it is limited to moral politics. Having part in the reformation, Muhammadiyah played a role as a counterweight representing the power of civil society against the government. Muhammadiyah channelled its aspirations through the media, the constitutional channel, along with other civil society forces (Argenti, 2017, pp. 82-104). Textually, the discourse of jihad meaning among Muhammadiyah discussions is jihad lil muwajahah, the struggle to face something by creating superior thing. One of its forms is constitutional jihad. This understanding of the meaning of Muhammadiyah's jihad can be applied to a counter-discourse on the dominant meaning of jihad, namely jihad as an act of terrorism (Romadlan, 2019, pp. 151-162).

One of the national politics played by Muhammadiyah is through the constitutional jihad, which is an effort to straighten the nation's direction. In the concept of nationalism, Muhammadiyah pledged darul abdi wassyahadah, namely the way of nationality in the Pancasila State (Wilindaya, 2018, pp. 33-44). Jihad from the perspective of Indonesian Muslim organisations, both Muhammadiyah and Nahdlatul Ulama, in the Indonesian post-reform era is defined as every struggle or effort carried out with the good faith and with the right intention to strengthen the words of truth, to bring about peace, to help humanity, without complicity or greed for personal gain, fame, wealth (Hammam \& Rahman, 2020, pp. 37-57).

\section{Constitutional jihad social movement}

During Muhammadiyah's one-century congress in Yogyakarta, Muhammadiyah manifested and actualized the meaning of jihad as an endeavour by mobilizing all capabilities (badlul juhdi) to create a prosperous, dignified, and sovereign life for all humankind. Muhammadiyah understands jihad as not a struggle with violence, conflict, and hostility. Jihad means the 
struggle of al-jihad li-al-muaradhah to fight with al-jibad li-al-muwaijahah, Muhammadiyah's understanding of jihad rests on the letter Al-Hujurat verse 15 (Romadlan, 2019, pp. 151-162; Hammam \& Rahman, 2020, pp. 37-57).

The constitutional jihad movement actualises the amar ma'ruf nabi munkar da'wah movement and the tajdid movement for renewal in the field of law to straighten the direction of the nation. The founder of Muhammadiyah, KH. Ahmad Dahlan succeeded in understanding the management of the Gede Kauman Mosque to straighten the path of prayer. Right now, Muhammadiyah is also struggling to untangle the nation's direction. It is mandated in the 1945 Constitution and Pancasila as the basis state (Wilindaya, 2018, pp. 33-44).

Table 2.

Muhammadiyah role

\begin{tabular}{ccccc}
\hline & $\begin{array}{c}\text { Muhammadiyah } \\
\text { constitution jihad } \\
\text { movement }\end{array}$ & $\begin{array}{c}\text { Social } \\
\text { movement }\end{array}$ & $\begin{array}{c}\text { Interest } \\
\text { group }\end{array}$ & Total \\
\hline $\begin{array}{c}\text { The head of } \\
\text { Muhammadiyah } \\
\text { centre }\end{array}$ & $50 \%$ & $37.27 \%$ & $12.73 \%$ & $100 \%$ \\
\hline
\end{tabular}

Based on the table above, it can be described that Muhammadiyah has played a role in influencing the passage of legislation. Muhammadiyah has a role in building the constitutional jihad movement with several (frequency $=50$ percent), giving influence in social movements of (frequency $=37.27$ percent), and Muhammadiyah as an interest group of (frequency $=12.73$ percent).

At the 46th Muhammadiyah Congressin 2010 in Yogyakarta, the head of Muhammadiyah centre declared a social movement against several laws that caused constitutional harm to the Indonesian people and threatened the state's sovereignty. The movement was named the "constitutional jihad" movement. The constitutional jihad movement has implications for Muhammadiyah's efforts to submit a judicial review to the constitutional court. However, in practice, all forms of power and efforts of Muhammadiyah are pro-actively involved in the political process of formulating legislation (RUU) which is also referred to as the constitutional jihad movement. 
Ijtihad: Jurnal Wacana Hukum Islam dan Kemanusiaan, Volume 21, No. 2, Desember 2021: 177-196

In the case of the ratification of the Omnibus Law on job creation, Muhammadiyah was actively involved in influencing public policy. Through the Law and Human Rights Council, the Muhammadiyah Central Executive, in collaboration with the Dean of the Faculty of Law and Heads of Muhammadiyah Law Colleges throughout Indonesia, held a focused group discussion (FGD) at the Faculty of Law, the University of Muhammadiyah Magelang on March 7, 2020. This discussion was intended to provide critical notes. The meeting accommodated the opinions, thoughts, ideas of academic groups who are members of the Dean Forum of the Faculty of Law, Muhammadiyah Higher Education, and Muhammadiyah leaders, especially from the Law and Human Rights Council.

The meeting identified four main problems of the Omnibus Law on job creation. First, the environment, spatial planning, and biodiversity. Second, risk-based licensing, implementation of government administration, and imposition of sanctions. Third, mineral, coal, and electricity mining. Finally, investment, employment, and micro, small, and medium enterprises (UMKM).

The results of the academic study then became the basis for the Muhammadiyah Central Executive in conveying the aspirations, criticisms, and views of the official position of the Muhammadiyah Central Executive in responding to the Omnibus Law on Job Creation.

\section{Figure 1.}

Political Opportunity

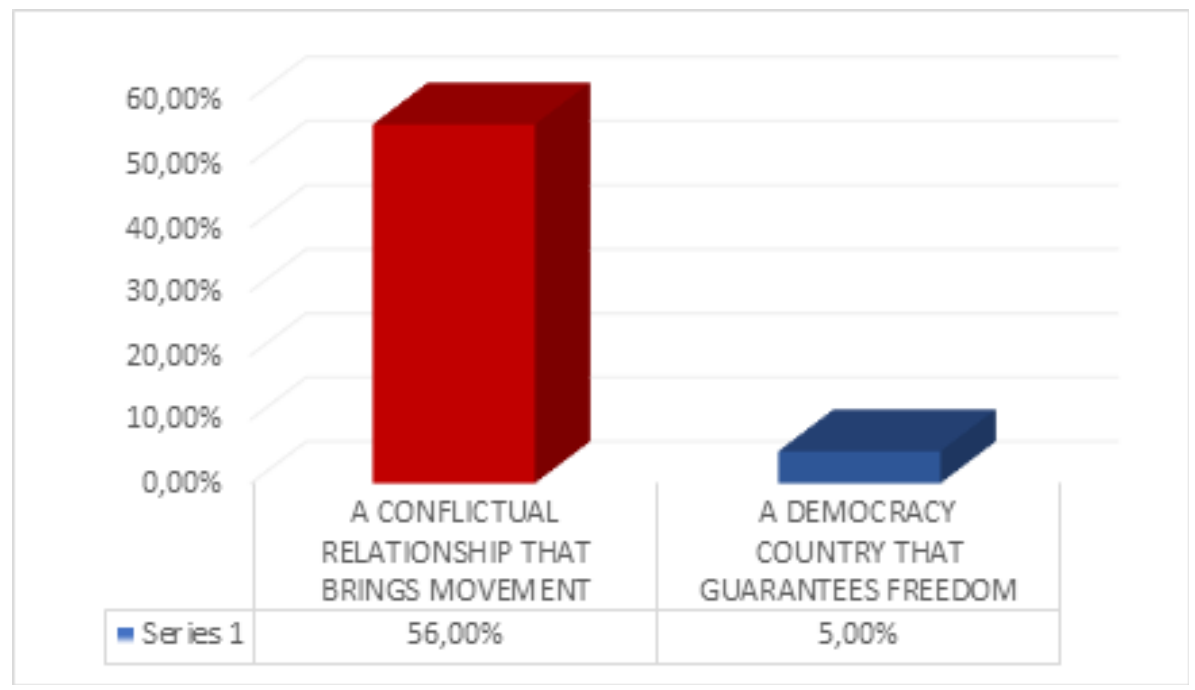


First, some conflicts are used by actors as a momentum to form the constitutional jihad movement. Second, the existence of a political system supports the emergence of social movements. In other words, the democratic state system provides an opportunity for the formation of a social movement, and this is marked by the opportunity to access public spaces, political institutions, and government agencies that can be accessed openly.

The graph above shows conflicts caused by dissatisfaction with the policy discourse of the Omnibus Law on job creation, so that it encourages the Muhammadiyah Central Executive to form the constitutional jihad movement. This conflictual relationship is described in the draft resume of focus group discussion on the job creation bill, which was prepared by the Muhammadiyah Central Leadership Law and Human Rights Council in collaboration with the Forum Deans of the Faculty of Law and Heads of Muhammadiyah Law Colleges throughout Indonesia.

Below are the draft statements. First, laws and regulations must be carried out based on the principle of openness. The flawed process in the discussion of the job creation bill opens the potential for public dissatisfaction to arise, and will lead to the rejection of the bill, thus open space for chaos in the community. Second, mutatis mutandis with the methods used in the discussion of the job creation bill, which tend to be closed, not transparent, not accountable, and involve very little public participation. Third, the technical thinking that the determination of the draft law on job creation through the omnibus method can make it efficient because the work has a wide area of regulation The technical thinking can be misleading because not everything is regulated is physical objects. Fourth, it concerns about the social impact of the issuance of this draft law, especially among workers. This draft law is deemed too partial and indulgent for businesspeople. Fifth, the house of representatives (DPR) should be able to determine the priority scale of the work agenda in the current emergency conditions to postpone the discussion of the Omnibus Law on job creation and focus more on guarding and supervising government policies and performance in tackling the Covid-19 pandemic outbreak. Hence, it can immediately overcome and end health, economic and social disasters.

Regarding conflictual relationship, the central executive of Muhammadiyah has the opportunity and ability to freely access public spaces, political institutions, and government agencies. This is called as political culture or political system that provides opportunities for 
the emergence of social movements. As democratic country, Indonesia provides freedom for civil society to express their aspirations in public spaces. Civil society and civil society organisations can access the public space access to political institutions through political party elites, and access to government agencies through meetings with the president of the Republic of Indonesia. There are meetings or interactions between the head of Muhammadiyah centre and several civil society organizations, and political party elites. This indicates that the political opportunity for the birth of the constitutional jihad movement in a democratic country like Indonesia is very widely open.

The constitutional jihad social movement got its political opportunity through the momentum of public dissatisfaction with the process of formulating and ratifying the Omnibus Law on job creation. This public disappointment has spread and become a conflict among civil society, the political elite, and the government. Then the constitutional jihad movement initiated by the Persyarikatan Muhammadiyah became more massive and received strong support as a social resistance movement because of its ability to mobilize the strength of various civil society organizations. In addition, the Persyarikatan Muhammadiyah has an open access to political institutions (leaders of political parties) and government agencies (President).

The structure mobilisation here is a condition where an organizational effort is made by social movement actors. 
Figure 2.

Structure mobilisation

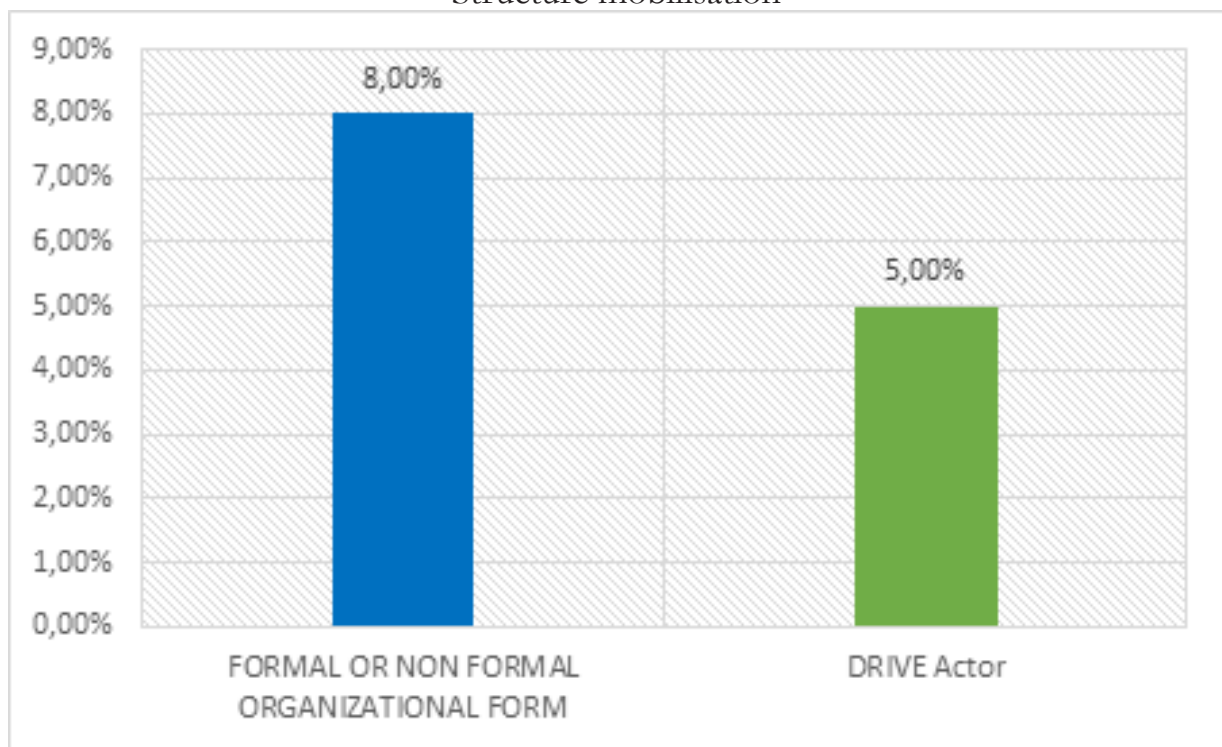

The graph above shows that there is a team consisting of several individuals. Hence, the constitutional jihad movement can be well organized and become the centre for formulating strategies to gather strength. Second, some actors move to encourage individuals and groups of individuals for supporting or even involving in the constitutional jihad movement.

The team of the Muhammadiyah Central Executive gave a mandate to conduct an academic study of the Omnibus Law on job creation and mobilise the strengths of various civil society organizations. The team that gave a mandate of the Muhammadiyah Central Executive is an assistant leadership element, that is the Muhammadiyah Central Executive Board of Law and Human Rights.

The mobilisation of the constitutional jihad structure was marked by a team that was given a mandate by the Central Leadership of Muhammadiyah to oversee the controversy over the Omnibus Law on job creation. The team was the Legal and Human Rights Council of the Muhammadiyah Central Executive. Then there are the driving actors who can mobilize the power to reject the Omnibus Law on job creation. The main actors in the constitutional jihad movement are Dr. Busyro Muqaddas, S.H., M.H, and Dr. Trisno 
ljtihad: Jurnal Wacana Hukum Islam dan Kemanusiaan, Volume 21, No. 2, Desember 2021: 177-196

Raharjo, S.H., M.H., where expected can gather strength from experts and academics from various universities and civil society organizations.

The feeling of disappointment with the Omnibus Law on job creation led to an action in mobilizing power by the Muhammadiyah Central Executive. The team played a significant role in actualizing feelings of disappointment into a massive and organized social movement to convey aspirations for the rejection of the Omnibus Law on job creation. In addition, the Muhammadiyah constitutional jihad social movement can be formed effectively because of the driving actors. They can build networks, become the inspiration for the movement with statements of attitudes and moral appeals, and have competence in law and public policy.

Transformation of social values forms a sense of solidarity. Transferring ideas or spreading ideas make an individual or group of individuals aware and support for the social movement.

Figure 3.

Movement framing process

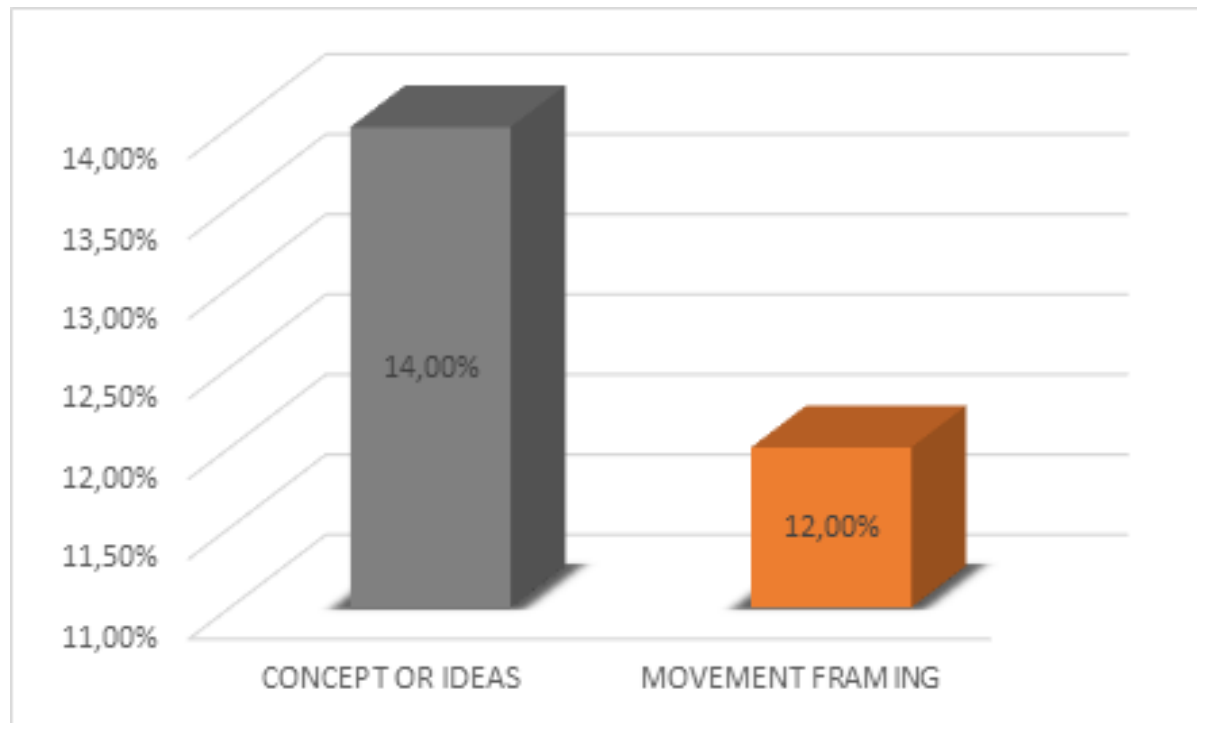

The graph above shows two fundamental information. First, there is an idealistic narrative of social values. The fundamental reasons raise the awareness of individuals or 
groups of individuals. Hence, they support and even get involved in the constitutional jihad movement. Second, there is a framing strategy for the constitutional jihad movement in a narrative of voiced aspirations.

The Muhammadiyah Central Executive delivered four statement points that some civil society organizations support it: First, the draft Omnibus Law on job creation should be transparent and disseminated as early as possible, with various philosophical and sociological foundations underlying the law. Second, ask the government to involve interested parties, especially from civil society elements. Third, the discussion of the omnibus job creation bill should be carried out with caution and prioritize the interests of the nation and state over the interests of certain business groups. Fourth, reject the draft Omnibus Law on job creation that have benefit for investors and exploit natural resources.

A transfer of social values is ideally formulating legislation that should be carried out transparently, involving public participation, prioritizing the state's interests, and not exploiting resources. The narrative of idealistic social values is to frame strategy and to raise awareness of an individual or group of individuals in supporting and even engaging in the movement to reject the Omnibus Law of copyright.

The framing process of the Muhammadiyah constitutional jihad movement was carried out by transferring idealistic social values and narrating demands through formal forums and mass media. These social values are the formulation of legislation that should be carried out transparently to public participation. That prioritises the state's interests and dose not exploit detrimental resources. Meanwhile, the narrative of aspirations is in the form of demands to revoke the Omnibus Law on Job Creation with the Government Regulation in Lieu of Law (PERPU)or postpone the implementation and revise the Omnibus Law on Job Creation.

\section{Conclusion}

The Muhammadiyah constitutional jihad strategy was carried out by forming a team to oversee the Omnibus Law on job creation, absorb the aspirations of the community and civil society organizations, and conduct academic studies with experts and academics in the field of law from various Muhammadiyah Universities along with other elements of 
the Persyarikatan Muhammadiyah. Results of the academic study are submitted to the president and leaders of the house of representatives of the Republic of Indonesia (DPR RI). Political opportunities, structural mobilization, and the process of framing the constitutional jihad movement can influence the causes of dissatisfaction with the omnibus law policy discourse formulated by the government of the Republic of Indonesia and the house of representatives of the Republic of Indonesia (DPR RI).

Some aspects of conflictual relationships emerged a movement that was initiated from public awareness. A democratic state guarantees freedom of expression to convey people's views. Muhammadiyah forms a formal or non-formal organization such as the Muhammadiyah Central Leadership Council for Law and Human Rights (HAM), forum of the dean of the law faculty and the head of the law colleges of law colleges Muhammadiyah and Aisyiyah universities. In Framing, the concept of Muhammadiyah emphasizes synchronization among institutions by prioritizing transparency and making laws severe in their implementation. Three concept points of Muhammadiyah are to revoke the Government Regulation in Lieu of Law (PERPU), delay its implementation, and revise it by inviting public participation.

\section{References}

Ahyar, M. (2015) "Membaca Gerakan Islam Radikal dan Deradikalisasi Gerakan Islam". Walisongo: Jurnal Penelitian Sosial Keagamaan, 23(1), 1. https://doi.org/10.21580/ ws.2015.23.1.220

Amin, M. (2020) “Gerakan Sosial Muhammadiyah di Era Reformasi”. Jurnal Ilmu Sosial Indonesia, 1(1), 36-45. https://doi.org/10.15408/jisi.v1i1.17108

Argenti, G. (2017) "Civil Society dan Politik Moral Muhammadiyah”. Jurnal Politikom Indonesiana, 2(2), 82-104. https://doi.org/10.35706/jpi.v2i2.968

Arizona, Y., \& Chandranegara, I. S. (2017) "Jihad Berkonstitusi: Muhammadiyah dan Perjuangan Konstitusional Melawan Komodifikasi Air". Wacana: Jurnal Transformasi Sosial, 35, 25-54. https://insistpress.com/wp-content/uploads/2017/12/Arizonadan-Chandranegara_Wacana-35-XIX-2017_25-54.pdf 
Muhammadiyah constitution jihad movement: ... (Muhammad Nurul Huda, et.al)

Azhar, M. (2019) “Omnibus Law sebagai Solusi Hiperregulasi Menuju Sonkronisasi Peraturan Per-Undang-undangan di Indonesia". Administrative Law and Governance Journal, 2(1), 170-178. https://doi.org/10.14710/alj.v2i1.170-178

Badrun, U. (2019) "Social Movement based on Religiosity as a New Model of Social Movements in Jakarta (The 212 Social Movement in Jakarta 2016)". International Journal of Multicultural and Multireligious Understanding, 6(4), 235. https://doi.org/10.18415/ ijmmu.v6i4.976

Bendar, A. (2019) "Feminisme dan Gerakan Sosial". Al-Wardah: Jurnal Kajian Perempuan, Gender Dan Agama, 13(1). https://doi.org/10.46339/al-wardah.v13i1.156

Brandão, C. (2015) "Qualitative Data Analysis with Nvivo, by P. Bazeley and K. Jackson". Qualitative Research in Psychology, 12(4), 1-3. https://doi.org/10.1080/14780887.2014. 992750

Buntoro, K., Nurmandi, A., Setiawan, A., \& Arie Saputra, H. (2021) Twitter Media Activities: Virtual Activism Related To China Uighur Muslim Problems. 12(1), 1-18. https://doi. org/10.31603/tarbiyatuna.v12i1.4115

Firmansyah, A. T., Sinaga, E. S., \& Aisyah, F. A. (2020) "Hilangnya Sendi Demokrasi dan Otonomi Daerah Melalui Korporatokrasi RUU Omnibus Law”. Widya Yuridika, 3(2), 131. https://doi.org/10.31328/wy.v3i2.1492

Fitri, A. I., \& Akbar, I. (2017) "Gerakan Sosial Perempuan Ekofeminisme di Pegunungan Kendeng Provinsi Jawa Tengah Melawan Pembangunan Tambang Semen”. CosmoGov, 3(1), 83. https://doi.org/10.24198/cosmogov.v3i1.12634

Fuadi, A., \& Tasmin, T. (2019) "Gerakan Sosial Baru di Ruang Publik Virtual”. Hanifya: Jurnal Studi Agama-Agama, 1(1), 48-60. https://doi.org/10.15575/hanifiya.v1i1.4261

Habibie, D. K., Nofrima, S., Pratama, P. Y., Saputra, H. A., \& Kurniawan, D. (2021) "Viewing Omnibus Law's Policy in a Governance Ethics Perspective through Social Media Twitter". Jurnal Public Policy, 7(1), 52. https://doi.org/10.35308/jpp.v7i1.3225

Hammam, \& Rahman, R. (2020) "Searching Meaning of Jihad for Indonesian Muslim in the Post Reformed Era of Indonesian Polity". RELIGLA: Jurnal Ilmu-Ilmu Keislaman, 23(1), 37-57. https:// doi.org/10.28918/religia.v23i1.2165 
ljtihad: Jurnal Wacana Hukum Islam dan Kemanusiaan, Volume 21, No. 2, Desember 2021: 177-196

Herdiana, D. (2018) “Sosialisasi Kebijakan Publik: Pengertian dan Konsep Dasar”. Jurnal Ilmiah Wawasan Insan Akademik, I(3), 13-26. http:/ / www.stiacimahi.ac.id/wp-content/ uploads/2019/12/2.-Dian-Herdiana.pdf

Izudin, A. (2018) “Gerakan Sosial dan Nalar Islam Progresif: Mencari Titik Temu Kerangka Metateori”. Jurnal Pemberdayaan Masyarakat: Media Pemikiran Dan Dakwah Pembangunan, 1(2), 281. https://doi.org/10.14421/jpm.2017.012-04

Kristiyanto, E. N. (2020) "Urgensi Omnibus Law dalam Percepatan Reformasi Regulasi dalam Perspektif Hukum Progresif (The Urgency of Omnibus Law to Accelerate Regulatory Reform in The Perspective of Progressive Law)". Jurnal Penelitian Hukum DE JURE, 20(2), 233-244. https://doi.org/10.30641/dejure.2020.V20.233-244

Kurniawan, F., \& Dewanto, W. A. (2020) "Problematika Pembentukan Ruu Cipta Kerja dengan Konsep Omnibus Law pada Klaster Ketenagakerjaan Pasal 89 Angka 45 Tentang Pemberian Pesangon Kepada Pekerja yang di PHK”. Jurnal Panorama Hukum, 5(1), 63-76. https://doi.org/10.21067/jph.v5i1.4437

Manulu, D. (2016) “Gerakan Sosial dan Perubahan Kebijakan Publik Kasus Perlawanan Masyarakat Batak vs PT. Inti Indorayon Utama di Porsea, Sumatera Utara”. Populasi, 18(1), 27-50. https://doi.org/10.22146/jp.12066

Masmuh, A. (2020) "Peran Muhammadiyah dalam Membangun Peradaban di Dunia". Gema Kampus IISIP YAPIS Biak, 15(1), 78-93. https://doi.org/10.52049/gemakampus. v15i1.107

Mayasari, I. (2020) “Kebijakan Reformasi Regulasi Melalui Implementasi Omnibus Law di Indonesia”. Jurnal Rechts Vinding: Media Pembinaan Hukum Nasional, 9(1), 1. https:/ / doi.org/10.33331/rechtsvinding.v9i1.401

Michael, T. (2020) "Bentuk Pemerintahan Perspektif Omnibus Law”. JurnalIus Constituendum, 5(1). https://doi.org/10.26623/jic.v5i1.1749

Moleong, L. J. (2017) Metode Penelitian Kualitatif(Ed Revisi). Bandung: Rosdakarya.

Mubaroq, H. H. (2019) "Interaksi antara Gerakan Sosial modernisme Muhammadiyah dengan Kegiatan Tradisional Yaqowiyyu di Jatinom”. JUSPI Jurnal Sejarah Peradaban Islam), 3(1), 42. https://doi.org/10.30829/juspi.v3i1.4076

Nilwani. (2016) “Kiprah Muhammadiyah dalam Kancah Politik Nasional”. Jurnal Tarbawi 
Muhammadiyah constitution jihad movement: ... (Muhammad Nurul Huda, et.al)

Khatulistiwa, 2(2), 33-43. https://doi.org/10.29406/.v2i2.247

Perrara, S. (2016) "Kinerja Komisi Penegak Etika Pemerintahan Daerah (KPEPD) dalam Mengimplementasikan Perda No. 1 Tahun 2008 tentang Etika Pemerintahan Daerah di Kota Solok Provinsi Sumatera Barat". Jurnal Online Fakultas Ilmu Sosial dan Ilmu Politik Universitas Riau, 1, 14. https://www.neliti.com/publications/33264/kinerjakomisi-penegak-etika-pemerintahan-daerah-kpepd-dalam-mengimplementasikan

Qodir, Z., Nurul Yamin, M., \& Nurmandi, A. (2015) Ijtihad Politik Muhammadiyab: Politite Sebagai Amal Usaha. Pustaka Pelajar. http://thesis.umy.ac.id/datapubliknonthesis/ EBUMY2056.pdf

Ramdhani, A., \& Ramdhani, M. A. (2017) "Konsep umum pelaksanaan kebijakan publik". Jurnal Publik, 11(01), 1-12. https://journal.uniga.ac.id/index.php/JPB/article/ view/1

Romadlan, S. (2019) "The Discourse of Meaning of Jihad in Muhammadiyah Circle (A Hermeneutics Perspective)". Komunikator, 11(2). https://doi.org/10.18196/ jkm.112028

Satria, A. P. (2020) "Sibernetika Talcott Parsons: Suatu Analisis Terhadap Omnibus Law dalam Pembentukan Undang-undang Cipta Lapangan Kerja di Indonesia”. Indonesian State Law Review, 2(2). https://doi.org/10.15294/islrev.v2i2.37317

Setiadi, W. (2020) "Simplifikasi Regulasi dengan Menggunakan Metode Pendekatan Omnibus Law". Jurnal Rechts Vinding, 9(1), 39-52. https://doi.org/10.33331/ rechtsvinding.v9i1.408

Setyawan, Y. (2020) "Rancangan Undang-undang Omnibus Law Cipta Kerja dalam Perspektif Undang-undang Nomor 12 tahun 2011 tentang Pembentukan Peraturan Perundang-undangan". Jurnal Ilmiah Hukum dan Keadilan, 7(1), 150-164. https:// ejurnal.stih-painan.ac.id/index.php/jihk/article/view/56

Sururi, A. (2016) "Inovasi Kebijakan Publik". Sawala: Jurnal Administrasi Negara, 4(3). https://doi.org/10.30656/sawala.v4i3.241

Van Gasse, D., \& Mortelmans, D. (2020) “Single mothers' perspectives on the combination of motherhood and work". Social Sciences, 9(5), 1-19. https://doi.org/10.3390/ SOCSCI9050085 
ljtihad: Jurnal Wacana Hukum Islam dan Kemanusiaan, Volume 21, No. 2, Desember 2021: 177-196

Wilindaya, I. (2018) “Menelaah Paham Kebangsaan Muhammadiyah". Jurnal An-Nida' Jurnal Pemikiran Islam, 42(2), 33-44. https:/ / doi.org/10.24014/an-nida.v42i2.9361

Yasmine, S. E. (2016) "Arab Spring: Islam dalam gerakan sosial dan demokrasi Timur Tengah”. Masyarakat, Kebudayaan Dan Politik, 28(2), 106. https://doi.org/10.20473/ mkp.v28i22015.106-113 